\title{
EU-Asia should defend multilateralism
}

\section{Fraser Cameron ${ }^{1}$}

Published online: 22 May 2020

C) Springer-Verlag GmbH Germany, part of Springer Nature 2020

Relations between the EU and Asia face an uncertain future as a result of the Coronavirus pandemic. Unlike after 2008-2009, when there was a coordinated global response to the financial crisis led by the USA, there has been no such response to Covid-19. States have turned inwards, closing borders and placing an emphasis on national as opposed to cooperative solutions. A bitter propaganda war between the USA and China has also had a negative impact on global cooperation. The implications of Covid-19 are likely to be far-reaching and will affect the balance of global power, economic structures, the role of multilateral agencies, patterns of social interaction and ways of work. Much will depend on the trajectory of the pandemic but governments will wish to mitigate the huge costs of the economic shutdown as soon as possible. Although national governments will give priority to restoring their own economies, they will soon learn that this can only be effective by global cooperation. In the absence of traditional US global leadership, there is now an opportunity for the EU and Asia to demonstrate the benefits of a cooperative approach to international relations.

\section{Multilateral failure}

Traditionally, Europe and Asia look to the USA in times of international crisis. From Truman to Obama, US presidents have set the agenda and mobilised allies and partners in a call to action. Unfortunately, President Trump has spent the last 3 years demeaning and degrading US allies in Europe and Asia. He has also denigrated multilateral institutions, including the EU, and spurned the idea that the USA should promote global collective action. His decision to suspend US funding for the World Health Organization was widely condemned, while his handling of the crisis at home has been an abject failure of leadership.

As a result, world leaders have done alarmingly little together to tackle the crisis. The United Nations Security Council has been silent. The G7 could not even agree on how to describe the pandemic with the USA insisting on calling it the Chinese or Wuhan virus. G20 leaders have had one short video conference that produced little

Fraser Cameron is the Director of the EU-Asia Centre in Brussels

Fraser Cameron

fc@eu-asiacentre.eu

1 EU-Asia Centre, Brussels, Belgium 
beyond vague promises to coordinate the recovery. Tellingly, there was no commitment to the multilateral trading system or the importance of fighting protectionism. In terms of financial stimulus, the $\$ 5$ trillion pledged was the same as in 2009 when the global economy was $25 \%$ lower.

\section{Propaganda war}

One of the major global trends in the past 3 years has been the steady deterioration in US-China relations. European and Asian countries have been inevitably caught up in the spat between the two major superpowers which has touched on trade and technology as well as security and now, propaganda. Asian governments have largely refrained from commenting on the propaganda war, although China received some support from Laos and Cambodia. In Europe, it initially gained some support in Italy and Spain but also criticism for providing faulty masks and testing equipment. Josep Borrell, the EU's foreign policy supremo, said that it was time for the 'battle of the narratives' to end and concentrate on global cooperation.

\section{EU response to Covid-19}

The initial response of the EU to Covid-19 was slow with member states preferring to concentrate on national efforts. While understandable in some ways, as health is largely a competence of the member states, it also revealed a lack of solidarity and a willingness to flout established rules about the single market and Schengen. Ursula von der Leyen put it bluntly when she said that the EU 'had been staring into an abyss.'

As the economic implications became clearer, the EU started to reassert itself. The European Central Bank unveiled a massive 750 billion euro loan facility, and there were further support measures from EU budget and the European Stability Mechanism. But there was no agreement on Eurobonds, thus demonstrating the on-going split in the EU, and leading to a drastic loss of public support for the EU in Italy and Spain. The EU, still coming to terms with Brexit, will inevitably take some time to recover its cohesion and move forward, but it cannot afford to remain inward-looking.

\section{Asian response to Covid-19}

With no supranational institutions to fall back on, Asian countries responded to the pandemic on the basis of their national interests. They were able, however, to draw on the experience of the 2003 SARS pandemic which affected Asia more than Europe. Travel restrictions and border closures became the new normal. ASEAN initially played little or no coordination role. The Asian Development Bank produced some additional money for Asian countries in most need while China also supplied medical equipment to friends in the region. Even when individual Asian countries took innovative steps to curb the virus, as with drive-in testing in South Korea, it was not followed elsewhere in Asia or Europe. The quality of governance, regardless of the system, was a key factor in tackling the crisis. At the same time several governments 
used the opportunity of the pandemic to increase their powers. Where there was agreement in all Asian countries was on the need for global cooperation to deal with the pandemic.

\section{Summitry}

Cooperation between the EU and Asia takes place at three levels. There is the continent to continent ASEM process, the region to region EU-ASEAN structures and there are the many bilateral contacts between the EU and Asian countries. With the ASEM summit scheduled to take place in Cambodia in November, the main agenda item should be how to strengthen the weakened multilateral institutions. The EU and ASEAN have agreed in principle to upgrade their relations to a strategic partnership but the entry into force has been delayed due to disputes over palm oil. Current priority issues, apart from Covid-19, include climate change and connectivity.

As regards the EU's strategic partners, it will be important to reinstate the four postponed summits as soon as possible, either live or virtual. Modi was due to visit Brussels in March, and EU leaders were due to visit Beijing, Tokyo and Seoul in the spring. There is also a special EU-China summit scheduled for Leipzig in September involving President Xi and all 27 member states. Billed as Merkel's swan song on the international stage, it was hoped to conclude a bilateral investment treaty. But this aim is in doubt given the problems of scheduling live meetings for the negotiating teams.

\section{An agenda for EU and Asia cooperation}

Faced with the biggest global crisis in the past 50 years, and in the absence of US leadership, the EU and Asia must work together to preserve and strengthen multilateral bodies and demonstrate the crucial importance of international cooperation. Their agenda should include the following:

a) Health: combatting the Covid-19 virus must be the top priority. There is more to be done in sharing best practices in how to contain the virus; and resources should be pooled in the search for a vaccine. The EU and Asia should also take the lead in strengthening the World Health Organization which has suffered some criticism for its handling of the crisis. It would be pointless trying to set up a rival body as some in the USA have suggested but reforms are necessary to restore confidence in the WHO. The EU and Asia should press for the WHO to have powers to monitor governments' health policies and ensure better exchange of information on health emergences and pandemics. Taiwan's observer status should be restored.

b) Economy: ensuring a swift economic recovery will be another priority for Europe and Asia. The world is heading into the worst recession in a century and unlike in the aftermath of 2008-2009, China will not be able to provide the needed financial stimulus. It has revised down its own growth rate for 2020 to $2 \%$ while most of Europe will be in minus figures. The EU and Asia should press the G20 to coordinate fiscal and monetary stimulus measures to avoid a beggar my neighbour approach. The EU and Asia should agree on specific measures including debt relief 
and a humanitarian rescue package for the worst hit countries in South Asia and sub-Saharan Africa.

c) Trade: the EU and Asia have a shared interest in preserving the World Trade Organization and pursuing its reform with the aim of regaining support from the USA. Several Asian countries have already joined the EU in establishing a provisional dispute settlement mechanism. There is now an urgent need for agreed rules on e-commerce and the digital economy as they are bound to gain in importance. There are strong voices in the USA calling for decoupling of economic ties with China. Whether companies wish to reconsider the resilience of their supply chains in light of the pandemic is up to them. But the emphasis should remain on pressing China to reform, not to try and isolate the second largest economy in the world.

d) Borders: the reopening of borders inside the EU and in Asia should be done in a coordinated way as it has obvious implications for transport links between Europe and Asia. If, as some have suggested, there may be an added health passport requirement to travel, this should be done in agreement. Tourism is a mainstay of the economies of many European and Asian countries.

e) Society: Europe and Asia might also reflect on how their respective societies have coped with the crisis and what might be the implications for society. A key debate will be how to narrow the gap between the 'haves' and 'have nots' under globalisation. There will be debates on the role of the state and on future working methods. What can Europe and Asia learn from each other on the use of digital technology, from education and health, to robotics and surveillance. What impact will the crisis have on attitudes to the work-life balance? Will governments still be judged largely on GDP performance? How has the crisis affected climate change? States will certainly wish to maintain new powers gained under the crisis, and it will be important for the future of our democracies to discuss the balance between state powers and individual freedoms. These are all issues worthy of debate between Europe and Asia in a variety of platforms involving all actors.

\section{Conclusion}

Although it has become common place to opine that Covid-19 will change the world, it is too early to say with confidence how the pandemic will change the global balance of power. Having experienced a short unipolar world after the end of the Cold War, we are now experiencing a multi-polar world, with the USA still the most important global actor. Another 4 years of Trump will accelerate the decline in US global leadership, the rise of xenophobia and erosion of US support for multilateral cooperation. On the other hand, a Biden victory could push the pendulum back toward a more active US role in the world.

Despite the controversy over the initial cover up of the virus, the death toll and the negative impact on its economy, China is gradually recovering its economic and political vigour. Xi Jinping has averted the biggest threat to his rule and to the authority of the Chinese Communist Party. Although its manufacturing engine is restarting, domestic and foreign demand will remain weak for some time. It is also not clear whether China's efforts in the 'battle of the narratives' will change impressions about China and its system of governance. 
The outcome of the US elections and China's positioning will have important consequences for the EU and the rest of Asia. But Europe and Asia cannot afford to wait and hope for the best. Together they have to work now to demonstrate, not only internal resilience, but an outward approach towards the global economic recovery. This will involve a rejection of protectionism and a strengthening of the multilateral system. The alternative is a return to the beggar my neighbour approach of the $1930 \mathrm{~s}$. And look where that ended.

Publisher's note Springer Nature remains neutral with regard to jurisdictional claims in published maps and institutional affiliations. 